\title{
Utilization of carbon nanotubes in hydrogen electrosynthesis from tropical fruit fermentation
}

\author{
Utilização de nanotubos de carbono na \\ eletrossíntese de hidrogênio a partir da \\ fermentação de frutas tropicais
}

Adriana Carla de Oliveira Lopes ${ }^{1}$, Fabiane Caxico de Abreu ${ }^{1}$

\author{
${ }^{1}$ Laboratório de Eletroquímica e Microssistema de Análises - LEMAN - IQB/UFAL, CEP: 57072-900, Maceió, AL, Bra- \\ sil \\ e-mail: caxico.fabiane@gmail.com, carla.oliveira.lopes@gmail.com
}

\begin{abstract}
The use of fossil fuels, especially oil and gas, has accelerated in recent years, resulting in the global energy crisis. The fermentative biological process is a sustainable way to produce hydrogen, as it can use as a substrate various types of carbohydrate-rich industrial and household waste such as fruit, minimizing but not completely eliminating the problems caused by improper disposal of this material. From a perspective of energy conservation and use of renewable sources for energy generation, this work aims to contribute to the identification of the use of a currently unused portion of energy, optimizing hydrogen production from a fuel cell. microbial. The main nanomaterial used in electrolysis was carbon nanotubes (CNT) incorporated into carbon felt (CF). Cyclic voltammetry studies were also performed on three electrode systems: vitreous carbon electrode as working electrode, platinum electrode as auxiliary electrode and $\mathrm{Ag} / \mathrm{AgCl} / \mathrm{Cl}^{-}$as reference electrode. An electrochemical cell formed by two separate compartments was constructed. Before starting the electrolysis experiment, an experimental design was performed using the complete factorial design technique to analyze the influence of the variables selected for this study. The independent variables selected were: Tropical fruit liquor concentration in $\% \mathrm{v} / \mathrm{v}$, type of working electrode, electrolysis time and $\mathrm{pH}$ of the electrolyte medium. The observed variable was the concentration in $\% \mathrm{v} / \mathrm{v}$ of the hydrogen gas obtained in the electrolysis. After the results of the tests, it was concluded that carbon nanotubes can be used as working electrode, presenting success in the hydrogen production process and that the $\mathrm{pH}$ of the electrolytic medium has a strong influence on this process. The present work was concluded presenting an alternative way in the production of a renewable energy source.
\end{abstract}

Keywords: Electrolysis, Tropical Fruits, Hydrogen.

\section{RESUMO}

O uso de combustíveis fósseis, especialmente petróleo e gás, acelerou nos últimos anos, o que está resultando na crise energética global. O processo biológico fermentativo é uma forma sustentável de produzir hidrogênio, já que pode utilizar, como substrato diversos tipos de resíduos industriais e domésticos ricos em carboidratos, como frutas, minimizando, mas não eliminando por completo, os problemas causados pelo descarte inadequado deste material. A partir de uma perspectiva de conservação de energia e uso de fontes renováveis para a geração de energia, este trabalho pretende contribuir para a identificação do uso de uma parcela de energia, atualmente inutilizada, otimizando a produção de hidrogênio a partir de uma célula de combustível microbiano. O nano material principal utilizado na eletrólise foi nanotubos de carbono (CNT) incorporados ao feltro de carbono (FC). Estudos de voltametria cíclica também foram realizados em três sistemas de eletrodos: eletrodo de carbono vítreo como eletrodo de trabalho, eletrodo de platina como eletrodo auxiliar e $\mathrm{Ag} / \mathrm{AgCl} / \mathrm{Cl}^{-} \mathrm{como}^{-}$ eletrodo de referência. Uma célula eletroquímica formada por dois compartimentos separados foi construída. Antes de iniciar o experimento de eletrólise, foi realizado um delineamento experimental utilizando a técnica de planejamento fatorial completo para analisar a influência das variáveis selecionadas para este estudo. As variáveis independentes selecionadas foram: Concentração de licor de frutas tropicais em $\% \mathrm{v} / \mathrm{v}$, tipo de eletrodo de trabalho, tempo de eletrólise e pH do meio eletrolítico. A variável observada foi a concentração em \%v/v do gás hidrogênio obtido na eletrólise. Após os resultados dos testes, concluiu-se que os nanotubos de carbono podem ser utilizados como eletrodo de trabalho, apresentando sucesso no processo de produção de hidrogênio e que o $\mathrm{pH}$ do meio eletrolítico exerce forte influência nesse processo. O presente 
trabalho foi concluído apresentando um caminho alternativo na produção de uma fonte de energia renovável.

Palavras-chave: Eletrólise, Frutas Tropicais, Hidrogênio.

\section{INTRODUCTION}

The growing demand for energy promotes a search for more efficient technologies in the energy generation field, economically viable and without generating environmental impact. With this, renewable energy sources such as wind, solar, hydraulics and biomass become the target of the researches for generation of clean energy. In this context, hydrogen is designated as the fuel of the future, being the energy vector with the highest energy potential, several routes for obtaining hydrogen are being developed, including water electrolysis, hydrocarbon reforming, gasification and thermochemical separation $[1,2]$. The hydrocarbon reform is the most used, being obtained from several sources such as natural gas, ethanol, biogas, etc. The main component of biogas is that methane, when applied in steam reforming methane, produces synthesis gas with a high $\mathrm{H}_{2} / \mathrm{CO}$ ratio, with pure hydrogen being applied to the fuel cell. The fuel cell are galvanic cells that generate electrical current through the chemical energy of fuels, converting $\mathrm{H}_{2}$ and $\mathrm{O}_{2}$ into water, heat and electrical energy [3]. The development of cell technology promotes a high efficiency in energy generation, without causing environmental impact, compared to combustion engines or motor generators that use combustion to generate energy and thereby emit pollutants harmful to the atmosphere, cells gain importance in the generation of energy efficiency [3, 4]. The fermentative biological process is a sustainable way of producing hydrogen, since it can use as substrate several types of industrial and domestic residues rich in carbohydrates, minimizing the problems caused by the inappropriate disposal of this material. Therefore, the use of agroindustry residues in the biological production of hydrogen has been investigated [5]. From a perspective of energy conservation and the use of renewable sources for the generation of energy, this work intends to produce biohydrogen using carbon nanotubes from the fermentation of tropical fruits. Red tropical fruits are rich in acids such as ascorbic acid (vitamin C) - $\mathrm{C}_{6} \mathrm{H}_{8} \mathrm{O}_{6}$ and ellagic acid $-\mathrm{C}_{14} \mathrm{H}_{6} \mathrm{O}_{8}$. These acids have great potential for producing hydrogen for fuel cells, since they offer high energy density, are non-toxic and can be handled safely in aqueous solutions [5, 6, 7]. Acid solutions can be used to produce hydrogen gas electrochemically, using solid metal electrodes. The energy employed is relatively low when compared to water electrolysis and shows an interesting economics, both financial and environmental [8, 9]. Studies of residues from the processing of fruit pulp used to produce hydrogen are still scarce and this biomass can become a good alternative in the development of microbial fuel cells. Thus, the present work proposes the use of biomass as an agent for the fermentation of tropical fruits, thus accelerating the existing enzymatic processes in the electrolytic medium through the formation of new compounds capable of optimizing the production of hydrogen gas through oxidation. The fermentation process, which was the starting point for the production of hydrogen, occurs by initiating the glycolysis process. This, in turn, is the central route of glucose catabolism, and pyruvate is the end product of this process, which may follow different metabolic pathways: alcoholic, lactic fermentation and respiration in the Krebs cycle and respiratory chain. Glycolysis is a metabolic sequence composed of a set of ten reactions catalyzed by free enzymes in the cytosol, in which glucose is oxidized producing two molecules of pyruvate, two molecules of ATP and two reduced equivalents of $\mathrm{NADH}^{+}$, which will be introduced into the respiratory chain or in fermentation. Glycolysis is one of the main routes for ATP generation in cells and is present in all tissue types $[1,3]$. Fermentation is a general term for the anaerobic degradation of glucose (anaerobic glycolysis) or other organic nutrients to obtain energy, preserved as ATP [1]. In this work the carbon nanotubes were used as working electrodes in the hydrogen gas electrosynthesis. Carbon nanotubes have been studied by scientists because they represent a great revolution thanks to its dimensions, its lightness and its extraordinary electrical, mechanical and thermal properties that surpass those of any previously known material $[8,10]$.

According to Nikolaidis [2] a wide variety of processes are available for $\mathrm{H}_{2}$ production which according to the raw materials used could be divided into two major categories namely, conventional and renewable technologies. The first category processes fossil fuels and includes the methods of hydrocarbon reforming and pyrolysis. In hydrocarbon reforming process, the participating chemical techniques are steam reforming, partial oxidation and autothermal steam reforming.

The second category accommodates the methods which produce hydrogen from renewable resources, either from biomass or water. Utilizing biomass as a feedstock, these methods can be subdivided into two general subcategories namely, thermochemical and biological processes. The thermochemical technology mainly involves pyrolysis, gasification, combustion and liquefaction, whereas the major biological processes are direct and indirect biophotolysis, dark fermentation, and photo-fermentation. The second class of renewable technologies regards the methods, which can produce $\mathrm{H}_{2}$ through water-splitting processes such as electrolysis, thermolysis and photo-electrolysis, utilizing water as the only material input.

In order to study the influence of the main variables of the hydrogen production process and to optimize the yield of this production, a factorial design of four variables was performed, which were fruit liquor concentration $(\% \mathrm{v} / \mathrm{v}),(20-50)$ type of working electrode $(\mathrm{CF}-\mathrm{CF}+\mathrm{CNT})$, electrolysis time $(\mathrm{h})(0.5-2)$ and $\mathrm{pH}(2-7)$ of the electrolytic medium. 


\section{MATERIAL AND METHODS}

According to Amorim's methodology [11], the sample of tropical fruits containing $100 \mathrm{~g}$ of strawberry, $100 \mathrm{~g}$ of acerola and $100 \mathrm{~g}$ of Pitanga, obtained commercially in nature, in the proportion of 1:2 by volume (tropical fruits / water), was submitted to a fermentation process for nine days. During the fermentation process daily measurements of $\mathrm{pH}$ and electrical conductivity were performed. After the fermentation process was interrupted, the sample was filtered, transformed into a fruit liquor and then frozen to be subjected to electrochemical studies. To verify the behavior of carbohydrate concentration, such as glucose, before and after fermentation, samples were analyzed to verify this concentration in mg / L. For these measurements, the method of Dubois et al. [12]. This method is based on the formation of furfural derivatives by heating neutral bones in concentrated sulfuric medium, which together with phenol form a yellow colored compound that can be measured by spectrophotometry at $490 \mathrm{~nm}$.

Before submitting the liquor to the electrolysis processes, studies of cyclic voltammetry were performed. These studies were carried out in three electrode systems: glassy carbon electrode as working electrode, platinum electrode as auxiliary electrode and $\mathrm{Ag} / \mathrm{AgCl} / \mathrm{Cl}^{-}$as reference electrode.

The voltammetry measurements were carried out with the aid of a potentiostat/galvanostat Autolab PGSTAT 302 (Eco Chemic, Utrecht, The Netherlands) coupled to a microcomputer equipped with a GPES interface for potential control, acquisition and data processing. From the peaks obtained in the initial voltammograms, an optimum potential for the electrolysis was fixed, varying the sample concentrations. Electrolysis was performed with different support electrolytes, providing different $\mathrm{pH}$ to the medium. These electrolytes were: potassium chloride $(\mathrm{KCl})$ in hydrochloric acid $(\mathrm{HCl}), \mathrm{pH}$ 2.5; Sodium acetate $\left(\mathrm{CH}_{3} \mathrm{COONa}\right)$ in acetic acid $\left(\mathrm{CH}_{3} \mathrm{COOH}\right), \mathrm{pH} 4.5$ and sodium phosphate monobasic $\left(\mathrm{NaH}_{2} \mathrm{PO}_{4}\right)$ in phosphoric acid $\left(\mathrm{H}_{3} \mathrm{PO}_{4}\right), \mathrm{pH} 7$.

The tests of cyclic voltammetry proved the passage of electric current in the circuit and that it has functional groups in molecules capable of undergoing redox processes. After the initial voltammetry studies, the first electrolysis with carbon felt electrode was performed as working electrode, platinum electrode as auxiliary electrode and $\mathrm{Ag} / \mathrm{AgCl} / \mathrm{Cl}^{-}$as reference electrode. The area of the electrode used was $1.53 \mathrm{~cm}^{2}$. The gases were collected in the gas burettes and their volumes were measured directly considering the temperature and the contribution of the partial pressure of the water. These values were used to calculate the efficiency of the electrolytic system.

In order to optimize current generation and electron transfer, the carbon felt electrode $(\mathrm{CF})$ has undergone a modification through incorporation with multi-walled carbon nanotubes (CNT). In this way, electrolysis was performed with the modified carbon felt electrode. The characterization teh surface morphology of the carbon felt electrode modified with carbon nanotubes were performed through Scanning Electron Microscopy (SEM).

The electrolytic cell was made by a U-shaped glazier, coupled to two burettes and two settling funnels, with two passages for the output of the gases produced, according to fig1. The total capacity of the cell is $85 \mathrm{~mL}$, but the volume of the electrolyte used was $50 \mathrm{~mL}$, this being the fermented liquor of the tropical fruits in different concentrations, diluted in buffer solutions of $\mathrm{KCl}$, acetate and phosphate to evaluate the production efficiency in different $\mathrm{pH}$ ranges.

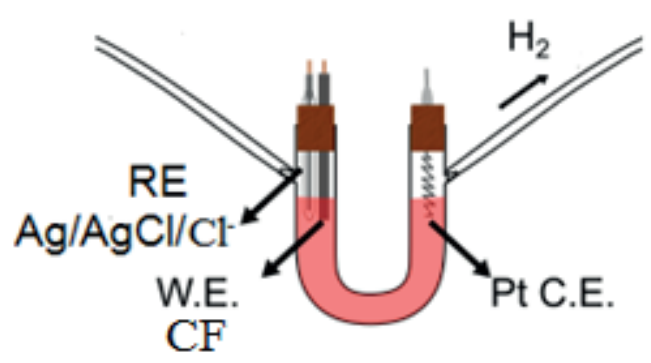

Figure 1: System for the production of hydrogen gas via electrolysis. 
The volume quantities of hydrogen gas produced were calculated by the electrolysis loads performed. To make sure that the gas produced was actually hydrogen, samples of fruit liquor after electrolysis were subjected to gas chromatographic analysis.

The concentration $\left(\mathrm{R}_{\%}\right)$ of the hydrogen gas in $\% \mathrm{v} / \mathrm{v}$ was calculated in relation to the volume quantity of hydrogen produced during the electrolysis, according to the value of the charge obtained and the total amount of volume of biogas produced, as shown in equation 1:

$$
R_{\%}=\frac{V_{H 2}}{V_{T}} \times 100
$$

At where:

$\mathrm{V}_{\mathrm{H} 2}$ is the amount of hydrogen produced during electrolysis;

$\mathrm{V}_{\mathrm{T}}$ is the total amount of biogas produced, obtained by visualizing the water displacement contained in the burettes coupled to the system.

The calculation of the volume of hydrogen in the normal temperature and pressure conditions (CNTP) from the reduction of $\mathrm{H}^{+}$in the cathode occurs with:

$$
2 \mathrm{H}^{+}+2 \mathrm{e}^{-} \rightarrow \mathrm{H}_{2}
$$

As a mole of gaseous $\mathrm{H}_{2}$ corresponds, under the normal conditions of temperature and pressure - CNTP, to a volume of $22.4 \mathrm{~L}$ and, if one mole of $\mathrm{H}_{2}$ is produced by the charge of $2 \mathrm{n} \times 96500 \mathrm{C}$, then the volume $\mathrm{V}$ given off by a charge $\mathrm{q}$ is given by equation 2 below:

$$
V=q \times \frac{22.4}{96500 \times 2 n}
$$

At where:

$\mathrm{q}$ is the charge obtained through the electrolysis process;

$\mathrm{n}$ corresponds to 1 mole of electrons;

22.4 L is the molar volume of the gas in CNTP;

$96500 \mathrm{C}$ is the electric charge relative to $1 \mathrm{~mol}$ of electrons.

To determine the experimental conditions that maximize the production of hydrogen, a saturated factorial experimental planning with 2 levels and 4 variables of the electrolysis process was carried out. The variables studied were: tropical fruit liquor concentration ( $\%$ by volume), type of working electrode, electrolytic time and $\mathrm{pH}$ of the electrolytic medium. The study interval of the variables is presented in Table 1.

Table 1: Study interval of the variables: Hydrogen Production via electrolysis.

\begin{tabular}{c|c}
\hline Variable & Values \\
\hline Concentration of red fruit liquor $(\% \mathrm{v} / \mathrm{v})$ & 20 and 50 \\
\hline Type of working electrode & carbon felt and carbon felt embedded in carbon nanotube \\
\hline Electrolysis time $(\mathrm{h})$ & 0.5 and 2 \\
\hline $\mathrm{pH}$ of the electrolytic medium & 2 and 7 \\
\hline
\end{tabular}

\section{RESULTS AND DISCUSSION}

\subsection{Fermentation process}

During the fermentation process, measurements of $\mathrm{pH}$ and electrical conductivity were carried out. The table 2 presents these measurements. From the sixth day of fermentation it was observed that the values of these measures were decreased until 
they remained constant over time indicating the presence of ethanol, the main product of the alcoholic fermentation. Thus, the fermentation was finalized since the presence of ethanol is not the interest of the present work. After this observation, it was concluded that the fermentation must be interrupted after five days of its beginning, mainly because after this time the conductivity decays, indicating the formation of ethanol which has low conductivity power. The electrical conductivity in the fermented fruit sample reaches its maximum value on the fifth day of fermentation, indicating that at this stage the sample is rich in $\mathrm{H}^{+}$species produced by the oxidation of the pyruvate and $\mathrm{NADH}$ compounds produced during the glycolysis process besides other species such as ascorbic acid found in the tropical fruits used [2]. The glucose results corroborate this observation because that values decrease after fermentation process $(27.63 \%)$.

Table 2: $\mathrm{pH}$ and conductivity measurements during the anaerobic fermentation process of fruits.

\begin{tabular}{ccc}
\hline Time & $\mathbf{p H}$ & Conductivity $(\boldsymbol{\mu S} / \mathbf{c m})$ \\
\hline 0 & 3.2 & 649.2 \\
\hline 1 day & 3.0 & 692.7 \\
\hline 2 days & 3.15 & 700.1 \\
\hline 3 days & 3.14 & 1397 \\
\hline 5 days & 3.15 & 1401 \\
\hline 6 days & 3.06 & 1378 \\
\hline 7 days & 3.1 & 1361 \\
\hline 8 days & 3.1 & 1360 \\
\hline 9 days & 3.1 & 1360 \\
\hline
\end{tabular}

\subsection{Work Electrode analysis}

The Figure 2 shows the scanning electron microscopy (SEM), before and after carbon felt modification with carbon nanotubes (CNT). The nanotubes are present on the surface of the carbon felt as can be observed in the highlight of the figure.

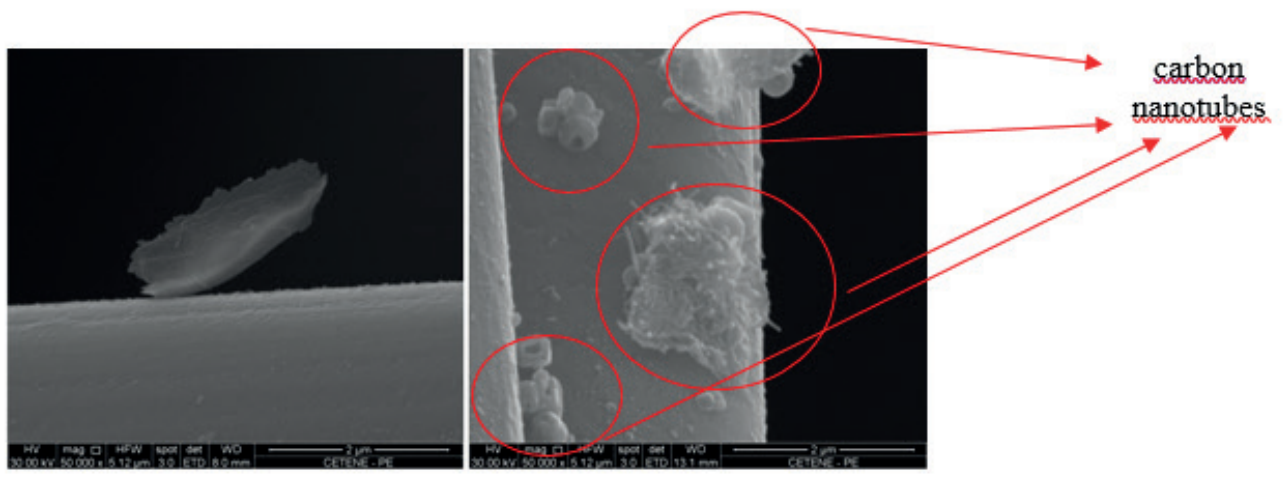

Figure 2: Scanning Electron Microscopy of carbon felt electrode modified with CNT.

\subsection{Cyclic voltammetry and electrolysis}

Electrochemical measurements were carried out in order to identify the general behavior of liquor on the static glassy carbon electrode. The electrochemical studies of $50 \% \mathrm{v} / \mathrm{v}$ tropical fruit liquor (rich in $\mathrm{H}^{+}$species produced in the glycolysis process during fruit fermentation) were performed in $0.2 \mathrm{~mol} \mathrm{~L}^{-1} \mathrm{KCl}$, buffer $\mathrm{pH}=2$, acetate buffer $0.2 \mathrm{~mol} \mathrm{~L}^{-1}, \mathrm{pH}=4.5$ and $0.2 \mathrm{~mol} \mathrm{~L}^{-1}$ phosphate buffer, $\mathrm{pH}$ 7.0. For both acetate and phosphate buffers electrolytes, as can be seen, an anodic wave, Fig3, is observed with a peak potential at $0.9 \mathrm{~V}$ and no reduction peak is observed, which indicate that this is an irreversible charge-transfer process. In addition, the displacement of the anodic peak potential to more positive values as a function of the scan speed corroborates the irreversibility of the system. After electrolysis using CF electrode, a similar behavior was observed. 


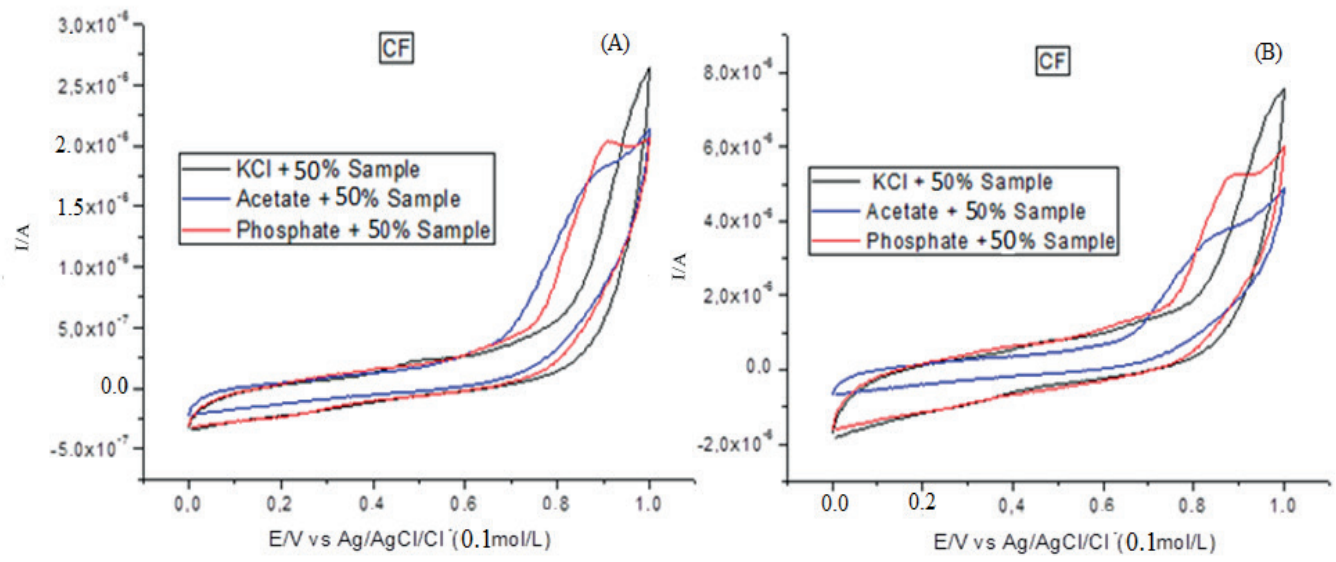

Figure 3: Cyclic voltammograms before (A) and after (B) electrolysis of fruit liquor using Carbon Felt electrode. Scan rate $0.100 \mathrm{~V} / \mathrm{s}$.

On the other hand, after electrolysis using CF + CNT electrode, the voltammograms for all medias (Fig4), presented a less positive oxidation peak potential and a better repeatability of analytical signals, which allowed the use of the electrode for many times. This oxidation system indicates the oxidation of acidic species such as pyruvate and ascorbic acid molecules present in fruits. The appearance of a second reversible anodic wave at $0.245 \mathrm{~V}$, shows the electrocatalysis of electron transfer due to the presence of carbon nanotubes in the working electrode. The recording of redox process can be associated the NADH. The probable formation of NADH during the fermentation process is of great importance because it transfers its electrons to molecules close to the beginning of the transport chain and as these electrons pass through the chain, they move from a higher energy level to one of lower energy, releasing energy. Part of this energy is used to pump $\mathrm{H}^{+}$ions (which during the electrolysis process will be reduced to $\mathrm{H}_{2}$ ), taking them out of the cell matrix and throwing them into the intermembrane space. This pumping establishes an electrochemical gradient [23].
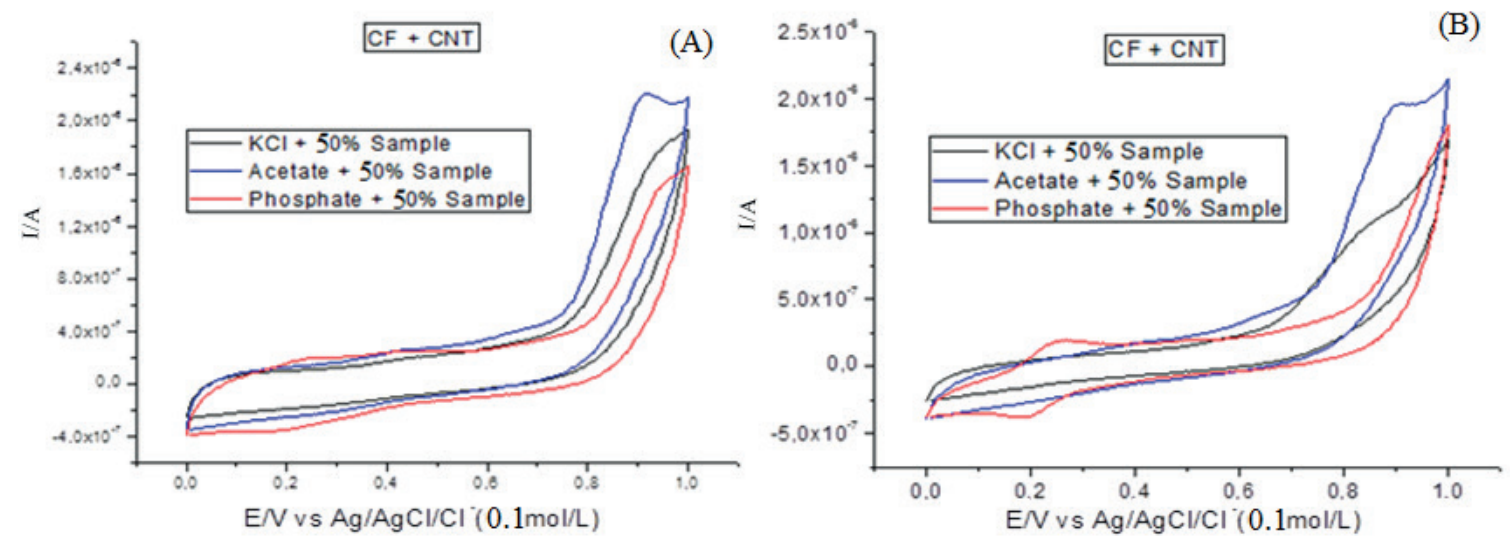

Figure 4: Cyclic voltammogram before (A) and after (B) of the electrolysis of the liquor fruit using Carbon Felt electrode modified with Carbon Nanotubes. Scan rate $0.100 \mathrm{~V} / \mathrm{s}$.

\subsection{Factorial planning results}

Table 4 presents the results of factorial design $2^{4}$, which shows the observed responses (hydrogen gas yield for each electrolysis) in all sixteen possible combinations of the chosen levels: concentration of the cell liquor in $\% \mathrm{v} / \mathrm{v}(20$ and $50 \%)$, type of working electrode $(\mathrm{CF}$ and $\mathrm{CF}+\mathrm{CNT})$, electrolysis time in $\mathrm{h}(0.5$ and $2 \mathrm{~h})$ and $\mathrm{pH}$ of the electrolytic medium $(2$ and 7). All assays were done in duplicate, producing thirty-two responses in total. The hydrogen gas yield responses are presented in the table 3 below. The study of factorial planning with four variables was of great importance, since it had the purpose of presenting which or which of the process variables influences the volume production of the hydrogen gas. 
Table 3: Results of a factorial design $2^{4}$ to study the effect of each selected factor on the yield of hydrogen gas obtained.

\begin{tabular}{|c|c|c|c|c|c|c|c|}
\hline \multirow{2}{*}{$\begin{array}{c}\text { Assay } \\
1\end{array}$} & \multirow{2}{*}{$\begin{array}{c}\begin{array}{c}\text { Concentra- } \\
\text { tion of liquor } \\
(\% \mathrm{v} / \mathrm{v})\end{array} \\
20\end{array}$} & \multirow{2}{*}{$\begin{array}{c}\begin{array}{c}\text { Type of Working } \\
\text { Electrode }\end{array} \\
\text { CF }\end{array}$} & \multirow{2}{*}{$\begin{array}{c}\text { Electrolysis } \\
\text { Time } \\
\text { (h) }\end{array}$} & \multirow{2}{*}{$\begin{array}{c}\text { pH of the } \\
\text { Electrolytic } \\
\text { medium } \\
2\end{array}$} & \multicolumn{2}{|c|}{$\begin{array}{c}\text { Hydrogen Gas } \\
\text { Yield (\%) }\end{array}$} & \multirow{2}{*}{$\begin{array}{c}\text { Average } \\
35.86\end{array}$} \\
\hline & & & & & 35.72 & 36.00 & \\
\hline 2 & 50 & $\mathrm{CF}$ & 0.5 & 2 & 43.23 & 41.20 & 42.21 \\
\hline 3 & 20 & $\mathrm{CF}+\mathrm{CNT}$ & 0.5 & 2 & 65.56 & 64.93 & 65.24 \\
\hline 4 & 50 & $\mathrm{CF}+\mathrm{CNT}$ & 0.5 & 2 & 82.13 & 82.45 & 82.29 \\
\hline 5 & 20 & $\mathrm{CF}$ & 2 & 2 & 36.34 & 35.87 & 36.10 \\
\hline 6 & 50 & $\mathrm{CF}$ & 2 & 2 & 46.45 & 44.89 & 45.67 \\
\hline 7 & 20 & $\mathrm{CF}+\mathrm{CNT}$ & 2 & 2 & 87.68 & 87.59 & 87.63 \\
\hline 8 & 50 & $\mathrm{CF}+\mathrm{CNT}$ & 2 & 2 & 88.21 & 88.73 & 88.47 \\
\hline 9 & 20 & $\mathrm{CF}$ & 0.5 & 7 & 78.54 & 78.12 & 78.33 \\
\hline 10 & 50 & $\mathrm{CF}$ & 0.5 & 7 & 89.67 & 90.00 & 90.83 \\
\hline 11 & 20 & $\mathrm{CF}+\mathrm{CNT}$ & 0.5 & 7 & 75.65 & 76.43 & 76.04 \\
\hline 12 & 50 & $\mathrm{CF}+\mathrm{CNT}$ & 0.5 & 7 & 86.51 & 85.94 & 86.22 \\
\hline 13 & 20 & $\mathrm{CF}$ & 2 & 7 & 57.89 & 57.61 & 57.75 \\
\hline 14 & 50 & $\mathrm{CF}$ & 2 & 7 & 89.55 & 88.95 & 89.25 \\
\hline 15 & 20 & $\mathrm{CF}+\mathrm{CNT}$ & 2 & 7 & 90.45 & 91.32 & 90.88 \\
\hline 16 & 50 & $\mathrm{CF}+\mathrm{CNT}$ & 2 & 7 & 94.52 & 93.97 & 94.24 \\
\hline
\end{tabular}

The pareto diagram (Fig5) graphically presents the effects of the studied variables as well as their effects of their interaction.

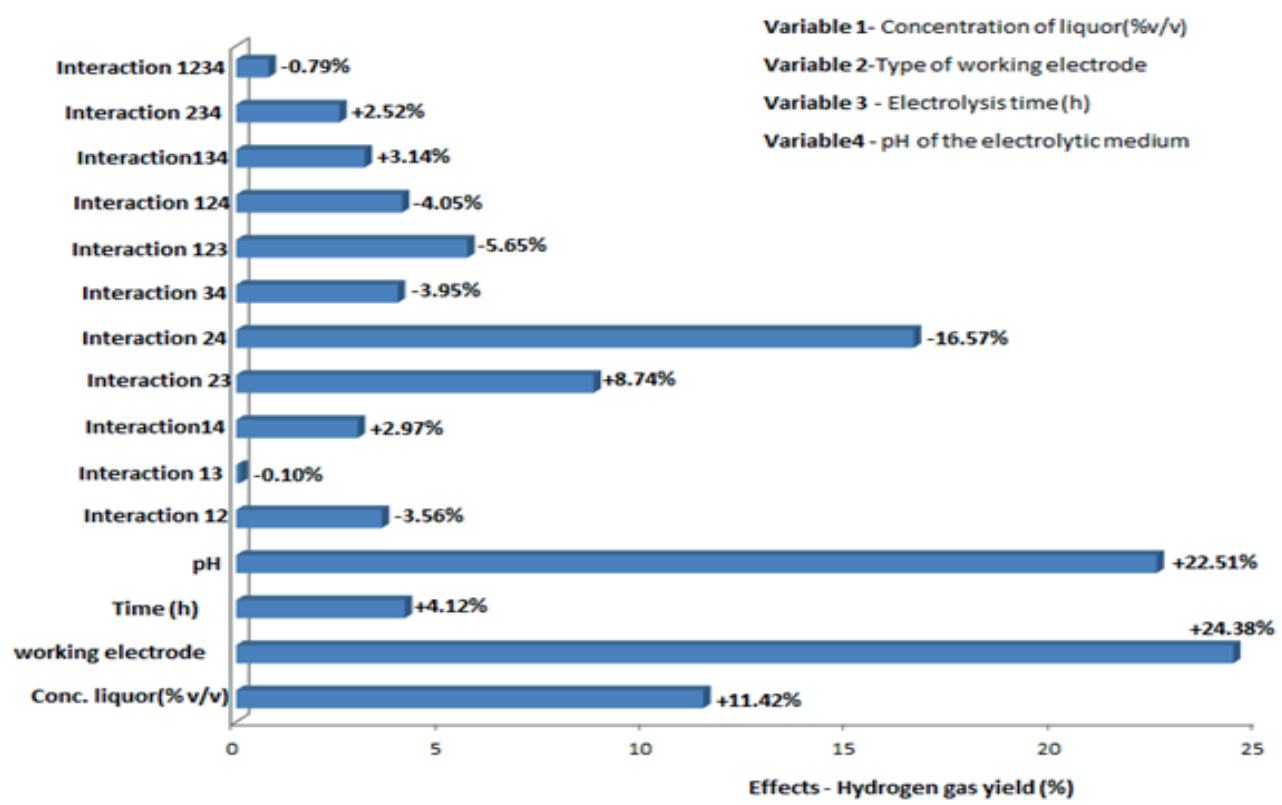

Figure 5: Pareto diagram for the effects of the variables.

Analyzing the figure 5, it can be concluded that the variables (electrode type and $\mathrm{pH}$ of the electrolytic medium) were the ones with the greatest effects, as well as the interaction of these variables. This is due to the increase in the electron transfer of the medium caused by the added carbon nanotubes. The neutral $\mathrm{pH}$ of the electrolytic medium also provided excellent conditions for increasing the yield of the hydrogen gas.

According to figure 5 and knowing that the minus sign (-) indicates a decrease in the yield of the hydrogen gas and 
the signal of $(+)$ indicates an increase in the yield of this gas, the following interpretations can be made:

It means that:

- If the concentration increases from 20 to $50 \%$ in v / v, keeping the other variables constant, the yield of hydrogen gas will increase by an average of $11.42 \%$;

- If the type of working electrode changes from $\mathrm{CF}$ to $\mathrm{CF}+\mathrm{CNT}$, keeping the other variables constant, the yield of the hydrogen gas will increase by an average of $24.38 \%$;

- If the electrolysis time increases from 0.5 to $2 \mathrm{~h}$, keeping the other variables constant, the yield of the hydrogen gas will increase by an average of $4.12 \%$;

- If the $\mathrm{pH}$ of the electrolytic medium increases from 2 to 7 , keeping the other variables constant, the yield of the hydrogen gas will increase by an average of $22.51 \%$;

- Interaction of variables 1 and 2: It means that if the concentration of the fruit liquor increases from 20 to $50 \% \mathrm{v} / \mathrm{v}$ and the type of working electrode change from $\mathrm{CF}$ to $\mathrm{CF}+\mathrm{CNT}$, keeping the other variables constant, the hydrogen gas yield will decrease, on average, $3.56 \%$;

- Interaction of variables 1 and 3: It means that if the concentration of the fruit liquor increases from 20 to $50 \% \mathrm{v} / \mathrm{v}$ and the electrolysis time increases from 0.5 to 2 hours, keeping the other variables constant, the hydrogen gas yield will decrease, on average, $0.10 \%$;

- Interaction of variables 1 and 4: It means that if the concentration of the fruit liquor increases from 20 to $50 \% \mathrm{v} / \mathrm{v}$ and $\mathrm{pH}$ of the electrolytic medium increases from 2 to 7, keeping the other variables constant, hydrogen gas yield will increase, on average, $2.97 \%$;

- Interaction of variables 2 and 3: It means that if the type of working electrode changes from CF to CF $+\mathrm{CNT}$ and the electrolysis time increases from 0.5 to 2 hours, keeping the other variables constant, the yield of the hydrogen gas will increase, on average, $8.74 \%$;

- Interaction of variables 2 and 4: It means that if the type of working electrode changes from CF to CF $+\mathrm{CNT}$ and the $\mathrm{pH}$ of the electrolytic medium increases from 2 to 7 , keeping the other variables constant, the hydrogen gas yield will decrease, on average, $16.57 \%$;

- Interaction of variables 3 and 4: It means that if the electrolysis time increases from 0.5 to 2 hours and the $\mathrm{pH}$ of the electrolytic medium increases from 2 to 7, keeping the other variables constant, the yield of the hydrogen gas will decrease, in mean, $3.95 \%$;

- Interaction of variables 1, 2 and 3: It means that if the concentration of the fruit liquor increases from 20 to $50 \% \mathrm{v}$ / v, the type of working electrode changes from CF to CF + CNT and the electrolysis time increases from 0,5 to 2 hours, keeping the fourth variable constant, the hydrogen gas yield will decrease, on average, $5.65 \%$;

- Interaction of variables 1, 2 and 4: It means that if the fruit liquor concentration increases from 20 to $50 \% \mathrm{v} / \mathrm{v}$, the type of working electrode changes from $\mathrm{CF}$ to $\mathrm{CF}+\mathrm{CNT}$ and the $\mathrm{pH}$ of the medium increases from 2 for 7 , keeping the third variable constant, the yield of hydrogen gas will decrease by an average of $4.05 \%$;

- Interaction of variables 1, 3 and 4: Means that if the fruit liquor concentration increases from 20 to $50 \% \mathrm{v} / \mathrm{v}$, the electrolysis time increases from 0.5 to 2 hours and the $\mathrm{pH}$ of the medium increases from 2 to 7 , keeping the second variable constant, the yield of hydrogen gas will increase, on average, $3.14 \%$;

- Interaction of variables 2, 3 and 4: It means that if the type of working electrode changes from CF to CF $+\mathrm{CNT}$, the electrolysis time increases from 0.5 to 2 hours and the medium $\mathrm{pH}$ increases from 2 to 7 , keeping the first variable constant, the yield of hydrogen gas will increase, on average, $2.52 \%$;

- Interaction of variables $1,2,3$ and 4: It means that if the four variables change simultaneously, the yield of the hydrogen gas will decrease, on average, $0.79 \%$.

\subsection{Comparison of biohydrogen production processes}

An overview of the major hydrogen production processes has been presented and then a comparative assessment is performed to evaluate both technical and economic aspects, while the relating data are summarized in Table 4. The Steam Reforming (SR) possesses the lowest operating temperature requiring no oxygen, followed by Autothermal Reforming (ATR) and Partial oxidation (POX), while hydrocarbon pyrolysis provides the advantage of being a reduced-step and 
emission-free procedure, with carbon as the only byproduct that requires treatment. Referring to Table 4, these methods are more advantageous, since they constitute a mature and highly developed technique for $\mathrm{H}_{2}$ generation through existing infrastructures. They also provide a more efficient conversion of energy (up to 85\%) compared to other renewable methods, what makes them, in most of the cases, the most viable approach. By combining membrane reactors with $\mathrm{H}_{2}$ generation from fossil fuels, further improvements occur in terms of efficiency, maximum temperature of operation and consequently capital investments. The low temperature $\left(550^{\circ} \mathrm{C}\right)$ achieved, could be provided from the exhaust gases of a gas turbine in a combined-cycle for both power and $\mathrm{H}_{2}$ production or even from concentrated solar energy. In contrast, the dependence on fossil fuels in combination with $\mathrm{CO}_{2}$ byproduct released in the atmosphere during the reforming process are the key limitations leading most researches to alternative and renewable methods. Since fossil fuels are currently used as both the reactants and the fuel for the process, these methods are heavily dependent on their price [6].

Biomass represents an abundant renewable feedstock available almost anywhere. The thermochemical pyrolysis and gasification offers an effective mean of hydrogen production (efficiency range of 35-50\%) while the fermentative processes provide the distinct advantage of simultaneous hydrogen generation and waste recycling, both modes having a neutral effect on $\mathrm{CO}_{2}$.

Table 4: Comparison of the different hydrogen production processes.

\begin{tabular}{|c|c|c|c|c|}
\hline Process & $\begin{array}{c}\text { Efficiency } \\
(\%)\end{array}$ & Major advantages & Major disadvantages & Ref. \\
\hline $\begin{array}{l}\text { Dark fermen- } \\
\text { tation }\end{array}$ & $60-80$ & $\begin{array}{l}\mathrm{CO}_{2} \text {-neutral, simple, can } \\
\text { produce } \mathrm{H}_{2} \text { without light, con- } \\
\text { tributes to waste } \\
\text { recycling, no } \mathrm{O}_{2} \text { limitation. }\end{array}$ & $\begin{array}{l}\text { Fatty acids removal, low } \mathrm{H}_{2} \\
\text { rates and yields, low con- ver- } \\
\text { sion efficiency, requirement of } \\
\text { large reactor volume. }\end{array}$ & [2] \\
\hline SR & $74-85$ & $\begin{array}{l}\text { Most developed technology, } \\
\text { existing infrastructure. }\end{array}$ & $\begin{array}{l}\mathrm{CO}_{2} \text { byproduct, depen- } \\
\text { dence on fossil fuels. }\end{array}$ & {$[2,13]$} \\
\hline POX & $60-75$ & $\begin{array}{l}\text { Proven technology, existing } \\
\text { infrastructure }\end{array}$ & $\begin{array}{l}\mathrm{CO}_{2} \text { byproduct, depen- } \\
\text { dence on fossil fuels } \\
\end{array}$ & {$[2,14]$} \\
\hline ATR & $60-75$ & $\begin{array}{l}\text { Proven technology, existing } \\
\text { infrastructure. }\end{array}$ & $\begin{array}{l}\mathrm{CO}_{2} \text { byproduct, depen- } \\
\text { dence on fossil fuels. }\end{array}$ & {$[2,15]$} \\
\hline CHs pyrolysis & - & $\begin{array}{l}\text { Emission-free, reduced-step } \\
\text { procedure. }\end{array}$ & $\begin{array}{l}\text { Carbon byproduct, depen- } \\
\text { dence on fossil fuels. }\end{array}$ & {$[2,16]$} \\
\hline $\begin{array}{c}\text { Biomass pyrol- } \\
\text { ysis }\end{array}$ & $35-50$ & $\begin{array}{l}\mathrm{CO}_{2} \text {-neutral, abundant and } \\
\text { cheap feedstock }\end{array}$ & $\begin{array}{l}\text { Tar formation, varying } \mathrm{H}_{2} \\
\text { content due to seasonal } \\
\text { availability and feedstock } \\
\text { impurities. }\end{array}$ & {$[2,17]$} \\
\hline $\begin{array}{l}\text { Biomass gasifi- } \\
\text { cation }\end{array}$ & - & $\begin{array}{l}\mathrm{CO}_{2} \text {-neutral, abundant and } \\
\text { cheap feedstock }\end{array}$ & $\begin{array}{l}\text { Tar formation, varying } \mathrm{H}_{2} \\
\text { content due to seasonal } \\
\text { availability and feedstock } \\
\text { impurities. }\end{array}$ & {$[2,18]$} \\
\hline Bio-photolysis & 10 & $\begin{array}{l}\mathrm{CO}_{2} \text {-consumed, } \mathrm{O}_{2} \text { is the only } \\
\text { byproduct, operation under } \\
\text { mild } \\
\text { conditions }\end{array}$ & $\begin{array}{l}\text { Requires sunlight, low } \mathrm{H}_{2} \\
\text { rates and yields, requirement } \\
\text { of large reactor volume, } \mathrm{O}_{2} \\
\text { sensitivity, high raw material } \\
\text { cost. }\end{array}$ & {$[2,19]$} \\
\hline $\begin{array}{l}\text { Photo-fermen- } \\
\text { tation }\end{array}$ & 0.1 & $\begin{array}{l}\mathrm{CO}_{2} \text {-neutral, contributes to } \\
\text { waste recycling, can use dif- } \\
\text { ferent organic. Wastes and } \\
\text { wastewaters. }\end{array}$ & $\begin{array}{l}\text { Requires sunlight, low } \mathrm{H}_{2} \\
\text { rates and yields, low conver- } \\
\text { sion efficiency, requirement } \\
\text { of large reactor volume, } \mathrm{O}_{2} \\
\text { sensitivity. }\end{array}$ & {$[2,20]$} \\
\hline Electrolysis & $40-60$ & $\begin{array}{l}\text { No pollution with renewable } \\
\text { sources, proven technology, exist- } \\
\text { ing infrastructure, abundant feed- } \\
\text { stock, O2 is the only byproduct, } \\
\text { contributes to RES integration as } \\
\text { an electricity storage option. }\end{array}$ & $\begin{array}{l}\text { Low overall efficiency, high } \\
\text { capital costs. }\end{array}$ & {$[2,21]$} \\
\hline
\end{tabular}




\begin{tabular}{c|c|l|l|c}
\hline Thermolysis & $20-45$ & $\begin{array}{l}\text { Clean and sustainable, abun- } \\
\text { dant feedstock, } \mathrm{O}_{2} \text { is the only } \\
\text { byproduct. }\end{array}$ & $\begin{array}{l}\text { Elements toxicity, corrosive } \\
\text { problems, high capital costs. }\end{array}$ & [2, 22] \\
\hline $\begin{array}{c}\text { Photo-electrol- } \\
\text { ysis }\end{array}$ & 0.06 & $\begin{array}{l}\text { Emission-free, abundant feed- } \\
\text { stock, O2 is the only byproduct. }\end{array}$ & $\begin{array}{l}\text { Requires sunlight, low con- } \\
\text { version efficiency, non-effec- } \\
\text { tive photocatalytic material. }\end{array}$ & {$[2,23,24]$} \\
\hline
\end{tabular}

Comparing the results of table 4 with the results obtained in the present work, it can be seen that the production of biohydrogen by the method presented here, had its production in $\% \mathrm{v} / \mathrm{v}$ ranging from $36-94 \%$, its greatest advantages are in the reuse of carbohydrate-rich agro-industry residues such as glucose, the raw material of the fermentation process and the use of a new hydrogen production technology involving the use of carbon nanotubes that have been shown to be efficient as a working electrode in hydrogen electrosynthesis. As a disadvantage one can mention the high cost of the electrolysis process, according to Levene [21] and Miranda [25].

Analyzing the results obtained in the present work, it is proved that the generation of waste from the agricultural sector can be seen as a great opportunity to add value to the biomass production chain for the production of $\mathrm{H}_{2}$, which can be used as a fuel source. mainly to its high net calorific value [26].

\section{CONCLUSIONS}

The experimental planning technique used in the present study improved the analytical methodology and made it possible to improve the analysis of the results after the end of the tests. This technique is already being used and has been shown to be very efficient in several experimental works [27]. The factorial planning methodology was a fundamental tool in the statistical study, providing reliable information about the process studied.

After the statistical study, using the technique of full factorial planning, we can see that the main effects 2, 4 and 1 correspond to the type of working electrode, $\mathrm{pH}$ of the electrolytic medium and concentration of the fruit liquor, respectively interactions between the two factors 24 (interaction between the type of working electrode and $\mathrm{pH}$ of electrolytic medium) and 23 (interaction between working electrode type and electrolysis time), showed significant effects in relation to the desired response that was the hydrogen gas yield.

According to Silva [26], the NADH formed in the process of the glycolytic pathway can undergo oxidation by losing the $\mathrm{H}^{+}$ion, which is reduced by forming the $\mathrm{H}_{2}$ molecule. This process probably occurred during the electrolysis process.

Analyzing the results obtained after the bench tests, it can be concluded that the carbon nanotube work electrode significantly increased the yield of the hydrogen gas, a fuel of high energy value renewable energy source [28], proving its excellents electrochemical properties presented in the literature.

\section{ACKNOWLEDGEMENT}

All the Laboratory of Electrochemistry and Microsystems-LEMAN analysis of Institute of Chemistry and Biotechnology-IQB from UFAL; CAPES, CNPq and FAPEAL for financial support.

\section{BIBLIOGRAPHY}

[1] MOMIRLAN, M, VEZIROGLU, T,N., "The properties of hydrogen as fuel tomorrow in sustainable energy system for a cleaner planet”. Int Journal Hydrogen Energy 2005; v. 30, pp. 795-802.

[2] NIKOLAIDIS, P, POULLIKKAS A, “A comparative overview of hydrogen production processes.” Journal of Renewable and Sustainable Energy Reviews; v. 67, pp. 597-611, Jan. 2017.

[3] LIN, L., ZHOU, W., GAO, R., "Low-temperature hydrogen production from water and methanol using Pt/ $\alpha-\mathrm{MoC}$ catalysts.” Journal of science and Sustainable Energy Reviews v. 544, pp. 80-83, Fev. 2017.

[4] VILla MONTOYA, A. C., Avaliação das caraterísticas físico-químicas e microbiológicas da produção de hidrogênio e homoacetogênese a partir de resíduos do processamento de café, Tese de D.Sc., UNIVERSIDADE DE SÃO PAULO, São Carlos, SP, Brasil, 2019. 
[5] MIRANDA, P. E. V., “Combustíveis - materiais essenciais para prover energia à nossa sociedade”, Matéria, V. 18, N.3, 2013.

[6] TANG, C., "Energy-saving electrolytic hydrogen generation: $\mathrm{Ni}_{2} \mathrm{P}$ nanoarray as a high-performance non-noble-metal electrocatalyst." Journal Angew Chemical. Int. Ed. Engl; v. 55, pp. 1-6, Feb. 2016.

[7] ZHU, Y. L., "Enhancing electrocatalytic activity of perovskite oxides by tuning cation deficiency for oxygen reduction and evolution reactions". Journal Cheical Mater; v. 28 pp. 1691-1697, Jun. 2016.

[8] JIANG, P., "Pt-like electrocatalytic behavior of $\mathrm{Ru}-\mathrm{MoO}_{2}$ nanocomposites for the hydrogen evolution reaction.” Journal Mater. Chemical A; v. 5, pp. 5475-5485, Feb. 2017.

[9] MAIZIA, R., DIB, A., THOMAS, A., MARTEMIANOV, S., "Proton exchange membrane fuel cell di-agnosis by spectral characterization of the electrochemical noise.” Journal Power Sources; v. 342, pp. 553-561, Jan. 2017.

[10] ASTAFEV, E. A., UKSHE, A. E., DOBROVOLSKY, Y., "Electrochemical noise of a hydrogen-air polymer electrolyte fuel cell operating at different loads". Journal of Solid State Electrochemistry, v. 22, pp. 1839-1849, Jun. 2018.

[11] AMORIM, E. L. C., BARROS, A. R., DAMIANOVIC, M. H. R. Z., et al. "Anaerobic fluidized bed reactor with expanded clay as support for hydrogen production through dark fermentation of glucose". International Journal of Hydrogen Energy, v.34, p.783-790, 2009.

[12] DUBOIS, M., GILLES, K. A., HAMILTON, J. K., et al. "Colorimetric Method for Determination of Sugars and Related Substances". Nature, v.28, n. 3, p.350-356, 1956.

[13] ERSÖZ, A., "Investigation of hydrocarbon reforming processes for micro-cogen-eration systems". Journal Hydrog Energy, v. 33, pp.7084-7086, Aug. 2008.

[14] STEINBERG, M., “ Modern and prospective technologies for hydrogen production from fossil fuels.” Journal Hydrog Energy; v. 14, pp. 797-820, Fev. 1989.

[15] HOLLADAY, J.D., HU, J., KING, D.L., “An overview of hydrogen production technologies.” Catal Today; v.139, pp. 244-246, Jun. 2009.

[16] MURADOV, N., "How to produce hydrogen from fossil fuels without $\mathrm{CO}_{2}$ emission." Journal Hydrog Energy, v. 18, pp. 211-214, Jan. 1993.

[17] DUMAN, G., UDDIN, M.A., YANIK, J., “Hydrogen production from algal biomass via steam gasification.” Bioresour Technol, v. 166, pp. 24-30, Jun. 2014.

[18] KAPDAN, I.K., KARGI, F., "Bio-hydrogen production from waste materials. Enzym Microb Technol” Journal Power Sources, v. 38, pp. 569-572, Fev. 2006.

[19] NI, M., LEUNG, D.Y.C., LEUNG, M,K,H., “An overview of hydrogen production from biomass”. Fuel Process Technol., v.87, pp. 461-463, Aug. 2006.

[20] KOTHARI, R,, BUDDHI, D., SAWHNEY, R.L., "Comparison of environmental and economic aspects of various hydrogen production methods.” Renew Sustain Energy Rev.; v. 12, pp. 553-557, Jan. 2008

[21] LEVENE, J.I., MANN, M.K., MARGOLIS, R.M., “An analysis of hydrogen production from renewable electricity sources." Sol Energy. v. 81, pp. 773-775, Aug. 2007.

[22] LIU, S., ZHU, J., CHEN, M., "Hydrogen production via catalytic pyrolysis of biomass in a two-stage fixed bed reactor system.” Journal Hydrog Energy; v. 39, pp. 13128-13130, Feb. 2014.

[23] DAS, D., VEZIROGLU, T.N., "Hydrogen production by biological processes: a survey of literature". Journal Hydrogen Energy, v. 26, pp. 13-28, 2001.

[24] PLESSIS, S. S., AGARWAL, A., MOHANTY, G., "Oxidative phosphorylation versus glycolysis: what fuel do spermatozoa use?.” Asian Journal Androl. v. 17, pp. 230-235, Fev. 2015.

[25] MIRANDA, P. E. V. “A energia do hidrogênio”, Matéria (Rio J.), v. 17, n. 1, 2012.

[26] SILVA MAZARELI, R. C., Otimização da produção de hidrogênio a partir de resíduos de banana: avaliação da diversidade de bactérias autóctones e distribuição funcional, Tese de D.Sc., UNIVERSIDADE DE SÃO PAULO, São Carlos, SP, Brasil, 2019.

[27] SILVA RABELO, C. A. B., Otimização da produção de hidrogênio e ácidos orgânicos em reator em batelada a partir de consórcio de bactérias autóctones e alóctones do bagaço de cana-de-açúcar Tese de D.Sc., UNIVERSIDADE DE SÃO PAULO, São Carlos, SP, Brasil, 2019. 
[28] ZUTTEL, A., "Materials for hydrogen storage.” Mater Today. v. 6, pp. 24-33, Feb. 2003.

\section{ORCID}

Adriana Carla de Oliveira Lopes Fabiane Caxico de Abreu http://orcid.org/0000-0001-5083-9718

https://orcid.org/0000-0002-9723-414X 